\title{
Index of Biotic Integrity based on fish assemblages for pampean streams and its implementation along the Del Azul stream (Buenos Aires province, Argentina)
}

Índice de integridade biótica baseado em assembleias de peixes em riachos pampeanos e sua implementação ao longo do riacho Del Azul (província de Buenos Aires, Argentina)

Ignacio Masson $^{1,2 *}$ (D), José Gonzalez Castelain ${ }^{1}$ (D), Sabrina Dubny $y^{1,3}$ (D), Natalia Othax ${ }^{1,3}$ (D) and Fabio Peluso ${ }^{1,2}$ (D)

${ }^{1}$ Instituto de Hidrología de Llanuras “Dr. Eduardo J. Usunoff”, Universidad Nacional del Centro de la Provincia de Buenos Aires - UNCPBA, República de Italia, 780 (B7300), Azul, Buenos Aires, Argentina

${ }^{2}$ Comisión de Investigaciones Científicas de la Provincia de Buenos Aires - CIC, Calle 526 e/10 y 11, La Plata, Buenos Aires, Argentina

${ }^{3}$ Consejo Nacional de Investigaciones Científicas y Técnicas de Argentina - CONICET, Av. Rivadavia 1917, (C1033AAJ) Ciudad Autónoma de Buenos Aires, Argentina *e-mail: imasson.ihlla@gmail.com

Cite as: Masson, I. et al. Index of Biotic Integrity based on fish assemblages for pampean streams and its implementation along the Del Azul stream (Buenos Aires province, Argentina). Acta Limnologica Brasiliensia, 2021, vol. 33, e4.

Abstract: Aim: Freshwater communities respond to abiotic and biotic changes in the environment, and are widely used as indicators of environmental integrity. Fish have been one of the most used biological groups for this purpose. The Del Azul stream located in the pampean region of Argentina has been monitored using a physicochemical approach with this monitoring being sporadic due to economic and operational constraints associated with the chemical analyses. In this paper we developed an Index of Biotic Integrity for the Del Azul stream (IBIA) based on Karr's Index of Biotic Integrity as an alternative. Methods: We computed two existent physicochemical indexes for comparison, one of them is the NSF-WQI and the other one is a local index referred to as Water Quality Index for Del Azul Stream and based on the former. Results: The three indexes followed similar trends along the examined reaches, showing good conditions in the upper basin, poor conditions just downstream of the urban area and a recovery state further downstream in the basin. Conclusions: Since the IBIA followed the same patterns as the physicochemical indexes, has a lower implementation cost and it is simpler to apply, we promote it as an alternative to the traditional physicochemical water quality monitoring for pampean streams.

Keywords: biomonitoring; pampean fish; water quality; IBI; neotropical ichthyofauna.

Resumo: Objetivo: Comunidades de água doce respondem a mudanças abióticas e bióticas no meio ambiente, sendo amplamente utilizadas como indicadores de integridade ambiental. Os peixes têm sido um dos grupos biológicos mais utilizados para esse fim. O riacho Del Azul, localizado na regiâo pampeana da Argentina, tem sido monitorado até agora usando uma abordagem físico-química, sendo esse monitoramento esporádico devido a restriçôes econômicas e operacionais associadas às análises químicas. Neste artigo, desenvolvemos um Índice de Integridade Biótica para o riacho Del 
Azul (IBIA) com base no Índice de Integridade Biótica de Karr como uma alternativa. Métodos: Calculamos dois índices físico-químicos existentes para comparação, sendo um deles o NSF-WQI e o outro um índice local referido como Índice de Qualidade da Água para o Riacho Del Azul que é baseado no primeiro. Resultados: Os três índices mostraram tendências semelhantes ao longo dos trechos examinados, detectando boas condiçôes no trecho superior da bacia, condiçóes mínimas no final da área urbana e recuperação em direção ao trecho inferior da bacia. Conclusóes: Como o IBIA segue os mesmos padrôes dos índices fisicoquímicos, tem menor custo de implantação e é mais simples de aplicar, o promovemos como alternativa ao tradicional monitoramento fisico-químico da qualidade da água para riachos pampeanos.

Palavras-chave: biomonitoramento; peixe pampeano; qualidade da água, IBI, ictiofauna neotropical.

\section{Introduction}

Indexes are useful tools in water resources management because they integrate a complex array of values into a single value easier to interpret (Madalina \& Gabriela, 2014). Further, indexes are of great help when evaluating the impacts of anthropic activities or the effectiveness of restoration programs (Abbasi \& Abbasi, 2012). Most water quality indexes are traditionally based on physicochemical variables (e.g., $\mathrm{pH}$, dissolved oxygen, temperature, turbidity, etc.), including in many cases microbiological variables such as bacterial loads (Landwehr \& Deininger, 1976; Mathuriau et al., 2011; Godwin \& Oborakpororo, 2019). However, physicochemical variables sometimes do not fully reflect the condition of a water body. They only show the conditions at the exact time of sampling which could not be coincident with sporadic pulses of pollutants. As well, the concentration of a targeted pollutant could be low enough to be detected by analytical methods but still harmful. Even if a substance is detected, it could be hard to establish the risk it represents when found in trace amounts, especially if its potential biohazard is not fully understood (Karr, 1981; Karr \& Chu, 2000; Springer, 2010; Holt \& Miller, 2011; Abbasi \& Abbasi, 2012). Instead, because aquatic organisms may tolerate a limited range of chemical, physical, and biological conditions, we can make use of them to evaluate the environmental quality of an ecosystem (Holt \& Miller, 2011). Using the biota for this purpose could also provide evidence not only of the present conditions but also of the past conditions or trends over time (Karr, 1981, 2006; Fausch et al., 1984; Karr et al., 1986; RodríguezOlarte \& Taphorn, 1995; Mathuriau et al., 2011).

There are several groups of organisms with biomonitoring potential including bacteria, protozoans, diatoms, algae, macrophytes, macroinvertebrates and fish (Abbasi \& Abbasi, 2012). Fish are one of the most studied biological groups of freshwater ecosystems, and by looking at their assemblage structure we can infer the condition of a waterbody (Karr, 1981; Fausch et al., 1990; Scardi et al., 2006; Gonino et al., 2020; Souza \& Vianna, 2020). Fish are particularly effective as biological indicators because they live in the water all their life, unlike many macroinvertebrates, and therefore, they continually inhabit the receiving water and integrate the chemical, physical and biological histories of the aquatic ecosystems; they are sensitive to several kinds of disturbances; they are excellent models in which to analyze responses to several stressors; unlike macroinvertebrates, most fish species have a long lifespan (i.e., about 2-10 years) and can reflect both long-term and current water quality; they are diverse in their feeding habits, and therefore, are able to integrate ecosystem health over larger spatial and temporal scales (LópezLópez \& Sedeño-Díaz, 2015). In this sense, fish are less affected by natural microhabitat differences than smaller organisms (e.g., macroinvertebrates), making them extremely useful for assessing regional and macrohabitat differences (Munné et al., 2015). Fish communities respond to environmental degradation by modifying their composition, for example, the proportion of species sensitive to pollution decline whereas tolerant species become dominant and trophic generalists prevail over specialists when specific food items become scarce, among others (Fausch et al., 1990). Aspects like these can be assessed through field sampling and used in multimetric indexes in which each single component metric represented by a biotic attribute, is predictably and reasonably related to specific impacts caused by environmental alterations (Hering et al., 2006).

One of the most used fish-based indexes is the Index of Biotic Integrity (IBI) originally developed by James Karr (1981) and subsequently used worldwide with diverse adjustments. The IBI is a measure of the biological integrity of an ecosystem based on the structure of the fish assemblages. The 
ecological basis of the IBI resides in that the highest levels in trophic webs (generally represented by fish in aquatic environments) require intact ecosystem functions and processes to survive, grow and reproduce.

The IBI and its variants have been applied on every continent except Antarctica (Karr\& Chu, 2000). Further, this approach has extensively been used with the neotropical ichthyofauna in Southern Brazil (e.g., Araujo, 1998; Araujo et al., 2003; Bozzetti \& Schulz, 2004; Marciano et al., 2004; Pinto et al., 2006; Pinto \& Araujo, 2007; Casatti et al., 2009; Eichbaum Esteves \& Alexandre, 2011; Gonino et al., 2020). In Argentina, the IBI has only been applied in the Suquía river (Córdoba province) where it proved to be useful for river health monitoring (Hued \& Bistoni, 2005). However, there are no records of its use in the watercourses of the pampean region of the country, the most productive ecoregion in terms of its suitability for agriculture and cattle farming (Matteucci et al., 2012). It is worth noting that the Suquía river belongs to a different ecoregion and basin and has a different ichthyofauna than pampean streams, despite sharing some species.

Despite not being done routinely, physicochemical monitoring has been the main water quality evaluation method for Del Azul stream. A specific water quality index was developed by Rodriguez et al. (2010) for this basin: the Water Quality Index for Del Azul Stream, hereafter referred to as WQIA. It is based on the NSF-WQI (Brown et al., 1970) with some modifications that make it more suitable to the local conditions, as indicated by the developers. However, mainly due to the cost of chemical analyses, the need of technological equipment for measurements as well as qualified technicians to operate them, it is not routinely utilized.

To contribute to the conservation and sustainable use of the Del Azul stream and other streams of the region, a dependable monitoring program is much desirable. With it in hand, new pollution sources or unsustainable practices in the basin could be identified. A fish-based multimetric index is considered a low-cost and a rapid means of assessing ecological integrity in streams (Gonino et al., 2020). Moreover, with little training and as most people are familiar with local fish species even the community could volunteer and contribute to the monitoring process by reporting the occurrence or absence of key species (USEPA, 1997; Callisto et al., 2012; França \& Callisto, 2017). It should be noted that the use of macroinvertebrates for biomonitoring has been more globally widespread than the use of fish (Rosenberg \& Resh, 1993; Bae et al., 2005; Buss et al., 2015) and that this biotic group has been suggested as even more effective than fish at distinguishing reference from impacted sites in neotropical streams of Brazil (Ruaro et al., 2016). Further, there is a specific biotic index based on benthic macroinvertebrates for pampean streams (Rodrigues Capítulo et al. 2001) as well as a biotic index based on diatoms for this same region (Licursi \& Gómez, 2003). Yet there are some difficulties associated with working with these biological groups of small organisms among which is that it requires taxonomic expertise (Karr, 1981). Fish instead are relatively easy to identify and technicians require relatively little training to recognize species. Indeed, most samples can be sorted and identified at the field site, with release of study organisms after processing (Karr 1981). In addition, it has been suggested that macroinvertebrates are best found in streams flowing over rocky beds and that lotic systems dominated by sediment (like pampean streams) makes monitoring of macroinvertebrates difficult and less reliable (Dickens et al., 2018).

Based on the hypothesis that the ichthyofauna responds to changes in environmental conditions and that due to this capability it could be used for stream biomonitoring, the objectives of our study were: (a) to develop an index of biotic integrity for the Del Azul stream based on the fish assemblage structure, (b) to compare its results among seven reaches along Del Azul stream with those from the traditional physicochemical water quality indexes. If both types of indexes follow similar trends, the biotic type could be adopted for stream health surveillance instead of the others due to its advantages, among which is a lower operative cost.

\section{Material and Methods}

\subsection{Study area}

The lowland streams of the pampean region are characterized by having a low flow rate due to the low land slope, high levels of suspended solids and silty sediment (Rodrigues Capítulo et al., 2010). Riparian forest vegetation is usually lacking and streams are generally surrounded by grasslands which in most cases have been converted to agricultural fields or used for cattle farming (Feijoó et al., 1999). These aquatic ecosystems are subjected to a temperate humid climate and commonly develop 
dense macrophyte communities (Giorgi et al., 2005; Rodrigues Capítulo et al., 2010).

The Del Azul stream basin is located in the center of Buenos Aires province (Figure 1). The stream is a natural tributary of the Salado del Sur river although the former's course has been artificially diverted in the early 1900's to prevent lowland flooding in case of water extremes (Claps, 1913). The study area belongs the pampean ecoregion (Matteucci et al., 2012). Annual precipitation is between 600 and $1200 \mathrm{~mm}$, and the mean annual temperature is $16{ }^{\circ} \mathrm{C}$. Even though precipitation is distributed throughout the year, maximum rainfall generally occurs in spring and autumn (Giorgi et al., 2005). The basin has $6,200 \mathrm{~km}^{2}$ and the stream itself is $160 \mathrm{~km}$ long. Its flow rate under normal conditions (i.e., no floods, no droughts) is $2-3 \mathrm{~mm}^{3} \mathrm{~s}^{-1}$ (Varni et al., 2019). There are not major changes along the watercourse in terms of substrate and vegetation except at the urban zone, as described further below.

The main land use in the basin is agriculture (e.g., soybean, corn, wheat, sunflower) followed by extensive cattle farming. Azul city with approximately 60,000 inhabitants is located $60 \mathrm{~km}$ downstream the watercourse origin (Entraigas \&
Vercelli, 2013). Although it is not an industrialized city, there are some point and non-point sources of potential pollution. The main point source discharge is the sewage treatment plant effluent located at the end of the urban zone. This facility is responsible for secondary treatment of wastewater from the city's sewer network. There are also many pluvial discharges into the stream along the urban zone. Among the non-point sources of potential pollution are the agricultural products used in the rural area.

In the urban zone, the stream has been widened and dredged at some locations to prevent city flooding in cases of extreme precipitation events. At its base flow, stream width is between 5 and $10 \mathrm{~m}$ with some exceptions excluded from the study (e.g., an artificially widened section in the urban middle basin devoted to aquatic recreation). In addition, stream banks in the urban zone are mowed and maintained by the Department of Public Works. At this zone, the stream is flanked by pedestrian walkways and streets. Several bridges cross the stream in this area.

The study was conducted at seven reaches along the Del Azul stream, covering the upper, medium and lower basin. Urban, pre-urban and post-urban

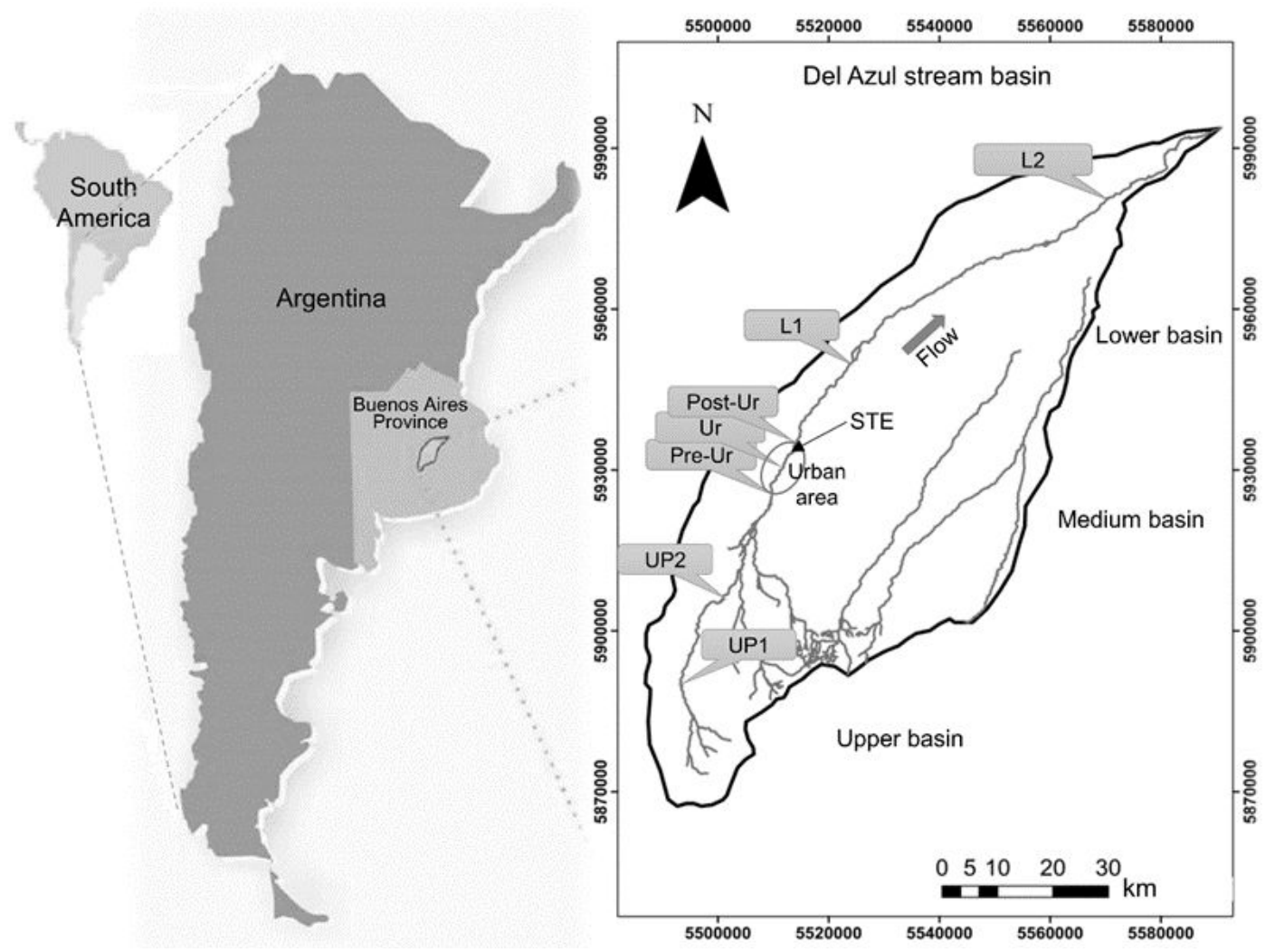

Figure 1. Location of the sampled reaches along the Del Azul stream. Please refer to the main text for reach acronyms meaning. STE: sewage treatment plant effluent. 
areas of the basin were considered into the analysis as well. The selected reaches have widths between 8 and $10 \mathrm{~m}$ and maximum depths of $0.75-1.00 \mathrm{~m}$ Although there is no reach completely excluded from human intervention in the entire basin such as a protected area, the most upstream basin reach could be thought as a reference site due to its close distance from the source. However, rather than using a reference site approach, the best observed values for each studied biotic attribute (i.e., metric) defined its maximum score (Karr, 1981; Harris \& Silveira, 1999).

Figure 1 shows the stream reaches selected for the study. Two of these reaches are located in the upper basin: "UP1" and "UP2". Three reaches are located in the middle basin: one of them being pre-urban ("Pre-Ur"), another being urban ("Ur") and another being post-urban ("Post-Ur"). The other two reaches are located in the lower part of the basin: "L1" and "L2". The following are their distances from the upstream origin: $16 \mathrm{~km}$ for "UP1", $41 \mathrm{~km}$ for "UP2", $59 \mathrm{~km}$ for "Pre-Ur", $65 \mathrm{~km}$ for "Ur", $69 \mathrm{~km}$ for "Post-Ur", $88 \mathrm{~km}$ for "L1" and $148 \mathrm{~km}$ for "L2".

\subsection{Sampling}

Eight sampling campaigns were performed during the study period: December 2015, February 2016, December 2016, February 2017, December 2017, February 2018, December 2018 and February 2019. The study was conducted during the summer.

To assess the fish assemblage structure the stream was seined at each studied reach. Similar habitattype reaches were selected based on the following: absence of canopy cover, maximum depths between 0.75 and $1.00 \mathrm{~m}$ (so they could be waded without risk) and existence of aquatic vegetation in the margins (potential refuge for fish). The stream substrate is similar along the watercourse with the coexistence of silty sediment and limestone patches. Seining was performed at five locations (i.e., five seine pulls) within a single reach. By sampling reaches of similar habitat characteristics we tried to ensure our results were as much comparable as possible. The dimensions of the seine were $5 \times 1 \mathrm{~m}^{2}$ (length $x$ height) with a mesh size of $5 \times 5 \mathrm{~mm}^{2}$. The seine was pulled by two people. The total seined area per reach was $50 \mathrm{~m}^{2}$.

Since aquatic vegetation serves as potential refuge for fish, we seined towards the vegetated banks. Floating or emerged macrophytes such as Ludwigia peploides., Hydrocotyle spp., Lemna spp. and Typha dominguensis were typically present along the sampled reaches. Captured fish were kept alive, identified to the species level, macroscopically checked for external parasites, injuries, deformities or other pathological signs and then, released on site.

Along with the biological assessment, temperature $\left({ }^{\circ} \mathrm{C}\right)$, dissolved oxygen concentration (DO) $\left(\mathrm{mg} \mathrm{L}^{-1}\right)$, electric conductivity (EC) $\left(\mu \mathrm{S} \mathrm{cm}^{-1}\right)$, turbidity (NTU) and $\mathrm{pH}$ were measured on site using portable equipment: YSI model 58 oximeter, Altronix CT2 conductivity meter, HANNA HI 93703 turbidity meter and Altronix TPA IV $\mathrm{pH}$ meter. Further, subsurface water samples were taken, stored at $4^{\circ} \mathrm{C}$ and brought to the laboratory for analysis. The variables accounted for in the laboratory were: 5-day biochemical oxygen demand (BOD), $\mathrm{NH}_{4}^{+}$, E. coli, total coliforms (TC), total aerobic microbial count (TAMC), $\mathrm{NO}_{3}^{-}, \mathrm{NO}_{2}^{-}$, $\mathrm{Na}^{+}, \mathrm{K}^{+}, \mathrm{F}^{-}, \mathrm{SO}_{4}^{-2}, \mathrm{PO}_{4}^{-3}$, suspended solids (SS), total solids (TS) and turbidity. Procedures from APHA (2005) were followed for the determinations. Pesticide analyses were not included due to budget constraints.

\subsection{Metric selection and data analysis}

To develop the biotic index for the Del Azul stream, we started by defining the candidate metrics that could contribute to distinguish environmental alterations based on available fish ecology literature. The following paragraphs present the proposed candidate metrics.

Diversity (Shannon's Index): Pristine reaches support more diverse fish communities than degraded ones (Karr, 1981; Karr et al., 1986; Fausch et al., 1990).

Dominance (Simpson's Index): As sensitive species disappear from degraded reaches tolerant species remain, with the latter becoming dominant (Casatti et al., 2009).

Native species richness: Pristine reaches generally support more native species than degraded ones (Harris \& Silveira, 1999; Ferreira \& Casatti, 2006).

Total abundance: pristine reaches generally sustain a higher number of fish than degraded ones (Karr, 1981; Karr et al., 1986; Fausch et al., 1990).

Omnivores (\%): When specific alimentary items are scarce, omnivores have an advantage over specialists. Thus, in degraded habitats, omnivores would be more represented than specialists (Karr et al., 1986). The captured species considered omnivorous were: Pimelodella laticeps (García et al., 2017), Rhamdia quelen (Gomes et al., 2000; Villares Junior \& Goitein, 2015), Corydoras paleatus 
(Escalante, 1983), Loricariichthys anus (Rosso, 2006), Hypostomus commersoni (Menni, 2004), Astyanax fasciatus (Esteves, 1996; Vilella et al., 2002), Astyanax eigenmanniorum (Vilella et al., 2002), Bryconamericus iheringii (Lampert et al., 2004; Kokubun et al., 2018), Cheirodon interruptus (Escalante, 1987), Cyphocharax voga (Diovisalvi et al., 2010; Fernandez et al., 2012), Cyprinus carpio (Colautti \& Remes Lenicov, 2001), Jenynsia multidentata (Iglesias et al., 2008; Quintans et al., 2009), Cnesterodon decemmaculatus (Quintans et al., 2009) and Mugil platanus (Oliveira \& Soares, 1996).

Carnivores (\%): As carnivores are positioned at the top of the food web, they need it to be integral and functional. Thus, carnivores are more sensitive to environmental degradation than omnivores (Karr, 1981; Karr \& Chu, 1999). The species considered carnivores were: Oligosarcus jenynsii (Nunes \& Hartz, 2006), Hoplias malabaricus (Carvalho et al., 2002; De Almeida et al., 1997) and Synbranchus marmoratus (Montenegro et al., 2012).

Characiforms (\%): Characiforms are less represented in reaches with increased turbidity. They are diurnal and mostly rely on their vison for feeding so they are expected to thrive better in clearer waters (Rodriguez \& Lewis Júnior, 1997; Pouilly \& Camacho, 2013).

Tetras (\%): Tetras are the most abundant characiforms in pampean streams. Tetras in the Del Azul stream are represented by $A$. fasciatus, $A$. eigenmanniorum, $B$. iheringi and $C$. interruptus (Rosso, 2006). They all belong to the family Characidae. Since it was cumbersome to differentiate $A$. fasciatus and $A$. eigenmanniorum in the field and because both species have similar ecological niches, they were pooled together as Astyanax spp.

Sick fish (\%): High numbers of fish presenting pathologies could indicate habitat impairment (Karr, 1981). Only macroscopic external pathologies were considered (e.g., worms, rashes, skin ulcers, etc.).

Fish tolerant to low DO (\%): Oxygen depletion is common in organically polluted reaches. Only species adapted to low oxygen concentrations would thrive better here. Species tolerant to low DO in the study area were: $R$. quelen (Braun et al., 2006), C. paleatus (Plaul et al., 2016), H. commersoni (Franco, 1994), H. malabaricus (Rantin et al., 1992), C. carpio (Hughes et al., 1983), J. multidentata (Hued et al., 2006),
C. decemmaculatus (Bistoni et al., 1999) and S. marmoratus (Eduardo et al., 1979).

Livebearers (\%): The livebearers J. multidentata (Anablepidae) and C. decenmmaculatus (Poeciliidae) are considered tolerant to poor water quality (Quintans et al., 2009). They are very prolific pseudoviviparous fish, omnivores and as they have their mouth pointing upwards it is believed that they could use water from the top layer richer in oxygen and thus withstand low DO waters (Rosso, 2006).

Note that dominance, omnivores, sick fish, fish tolerant to low DO and livebearers are negative metrics. This means that the higher their value the lower they contribute to the overall biotic index score.

Following Karr (1981), the best and the worst observations for each metric were attributed a score of 10 and 0 , respectively. Intermediatevalue observations received proportional scores. The biotic index is given by the sum of the metric scores. The suitability of each metric for being a definitive constituent of the biotic index was tested by performing regression analysis between each one of the candidate metrics and a preliminary biotic index calculated with all the candidate metrics. Only the metrics showing a significant correlation $(\mathrm{p}<0.05)$ with the preliminary biotic index were incorporated to the final or definitive biotic index for the Del Azul stream, hereafter referred to as IBIA.

The NSF-WQI and the WQIA were computed by entering the collected physicochemical data to already existent informatic tools. In the former case, an online calculator is available at the Water Research Center website (Water Research Center, 2021). The variables considered by the NSF-WQI are: $\mathrm{DO}, \mathrm{TC}, \mathrm{pH}, \mathrm{BOD}$, temperature change, $\mathrm{PO}_{4}^{-3}, \mathrm{NO}_{3}^{-}$, Turbidity and TS. To compute the WQIA, a Microsoft Excel-based program was used which was provided by the developers of the local index (Rodríguez et al., 2010). The WQIA takes into account 14 variables: $\mathrm{BOD}, \mathrm{NH}_{4}^{+}$, E. coli, TC, $\mathrm{NO}_{3}^{-}, \mathrm{NO}_{2}^{-}, \mathrm{EC}, \mathrm{Na}^{+}, \mathrm{K}^{+}, \mathrm{F}^{-}, \mathrm{SO}_{4}^{-2}, \mathrm{SS}$, TS and turbidity. In both cases, indexes' scores below 49 indicate bad water quality.

Statistical differences in mean IBIA, mean NSF-WQI and mean WQIA values were tested using the Kruskal-Wallis test due to the parametric requirements for ANOVA were not met (Zar, 2014). The significance level in all cases was 0.05 . The statistical software used for the analyses was Past v3.26 (Hammer et al., 2001). 


\section{Results}

A total of 5,036 individual fish were captured throughout the sampling period. Table 1 presents a list of the species caught during the study, their abundance and percentage.

The metrics that showed significant relationship with the preliminary IBIA $(\mathrm{p}<0.05)$ were: native species richness, diversity, dominance, percentage of carnivorous fish, percentage of characiforms, percentage of tetras, percentage of fish tolerant to low DO and percentage of livebearers (Table 2). In order to avoid metric redundancy, we tested for inter-correlation among metrics. We detected that the "percentage of characiforms" and the "percentage of tetras" were highly correlated $(R=0.97, p<0.05)$ and the "Shannon's diversity index" was highly correlated with the "Simpson's dominance index" $(\mathrm{R}=-0.97, \mathrm{p}<0.05)$. To deal with this redundancy issue we chose one metric of each pair based on how good that metric was correlated with the preliminary IBIA (Table 2). In the case of the former pair we chose to keep the "Shannon's diversity index" since it had a higher R-value (absolute value) than the "Simpson's Dominance Index": 0.44 vs. -0.38 , respectively. In the case of the later metric pair, we chose to keep the "percentage of tetras" because it had a slightly higher R-value than the "percentage of characiforms": 0.65 vs. 0.64 , respectively. The other metrics which showed significant inter-correlations $(\mathrm{p}<0.05)$ were "percentage of livebearers" and "percentage of fish tolerant to low DO" $(\mathrm{R}=0.89)$, "percentage of tetras" and "percentage of fish tolerant to low DO" $(\mathrm{R}=-0.87)$, "percentage of livebearers" and "percentage of characiforms" ( $\mathrm{R}=-0.8262)$, "Shannon's diversity index" and "Native species richness" $(\mathrm{R}=0.67)$,

Table 1. List of the species collected at the Del Azul stream during the period of the study. Number of individuals of each species (N) and relative abundance (\%). All species are native except for Cyprinus carpio.

\begin{tabular}{|c|c|c|c|}
\hline Order & Species & $\mathbf{N}$ & $\%$ \\
\hline \multirow[t]{5}{*}{ SILURIFORMES } & Pimelodella laticeps & 131 & 2.60 \\
\hline & Rhamdia quelen & 36 & 0.71 \\
\hline & Corydoras paleatus & 85 & 1.69 \\
\hline & Loricariichthys anus & 28 & 0.56 \\
\hline & Hypostomus commersoni & 48 & 0.95 \\
\hline \multirow[t]{6}{*}{ CHARACIFORMES } & Astyanax spp. (A. fasciatus and A. eigenmanniorum) & 1,009 & 20.04 \\
\hline & Bryconamericus iheringi & 305 & 6.06 \\
\hline & Cheirodon interruptus & 1,257 & 24.96 \\
\hline & Oligosarcus jenynsii & 104 & 2.07 \\
\hline & Cyphocharax voga & 11 & 0.22 \\
\hline & Hoplias malabaricus & 9 & 0.18 \\
\hline CYPRINIFORMES & Cyprinus carpio & 14 & 0.28 \\
\hline \multirow[t]{2}{*}{ CYPRINIDONTIFORMES } & Jenynsia multidentata & 1,162 & 23.07 \\
\hline & Cnesterodon decemmaculatus & 573 & 11.38 \\
\hline SYNBRANCHIFORMES & Synbranchus marmoratus & 5 & 0.10 \\
\hline PERCIFORMES & Australoheros facetus & 259 & 5.14 \\
\hline Total & 17 species & 5,036 & 100 \\
\hline
\end{tabular}

Table 2. Pearson correlation coefficients $(\mathrm{R})$ and probabilities $(\mathrm{p})$ for the relationships between each of the candidate metrics and the preliminary IBIA.

\begin{tabular}{lcc}
\hline \multicolumn{1}{c}{ Candidate metrics } & $\mathbf{R}$ & $\mathbf{p}$ \\
\hline Native species richness & 0.4828 & 0.001 \\
Total Abundance & 0.0019 & 0.991 \\
Omnivores (\%) & -0.2398 & 0.121 \\
Carnivores (\%) & 0.3103 & 0.043 \\
Characiforms (\%) & 0.6384 & $<0.001$ \\
Sick fish (\%) & 0.1272 & 0.416 \\
Fish tolerant to low DO (\%) & -0.6457 & $<0.001$ \\
Tetras (\%) & 0.6475 & $<0.001$ \\
Livebearers (\%) & -0.5842 & 0.000 \\
Shannon's diversity index & 0.4429 & 0.003 \\
Simpson's dominance index & -0.3776 & 0.013 \\
\hline
\end{tabular}

DO: dissolved oxygen concentration. 
and "percentage of livebearers" and "percentage of carnivorous fish" $(R=-0.28)$. Due to some intercorrelation among metrics is expected (i.e., all tested metrics are intended to respond to impaired habitat conditions so it is no surprising that some of them inter-correlate to some extent), we chose to leave the ones with R-values below 0.9 not to largely deprive the index of metrics. Further, it is common to see metrics like these together in other biotic indexes (e.g., Karr, 1981; Hued \& Bistoni, 2005; Pinto \& Araujo, 2007; Casatti et al., 2009).

After the metric selection procedure, we ended up with six metrics for the definitive IBIA: native species richness, diversity, percentage of carnivorous fish, percentage of tetras, percentage of livebearers and percentage of fish tolerant to low DO. As we got six suitable metrics and the maximum possible score for each one is ten ( $0-10$ scale), then the best possible score for our final IBIA is 60 . Nonetheless, we converted our IBIA 0-60 score to percentage to facilitate comparison with the physicochemical indexes which both are expressed on a 0-100 scale.

Figure 2 and Table 3 show the mean IBIA, WQIA and NSF-WQI mean scores at each of

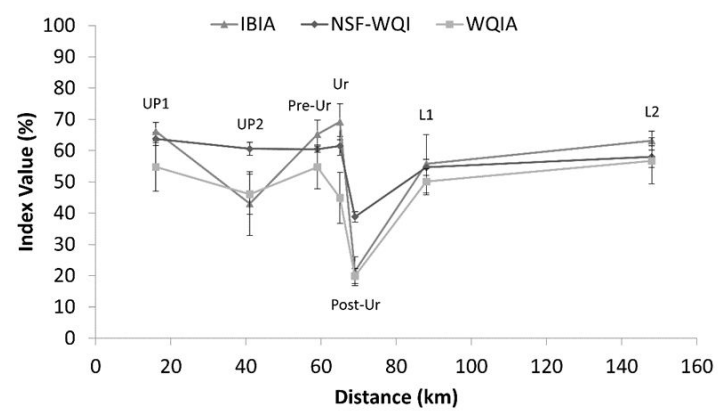

Figure 2. IBIA, WQIA and NSF-WQI scores at seven reaches along the Del Azul stream. Reaches are arranged by their distance from the stream origin. Error bars represent the standard error of the mean. Lines connect scores belonging to the same type of index and do not imply intermediate values. Please refer to the main text for reach acronyms meaning. the sampled reaches. All three indexes showed a minimum at "Post-Ur", the reach located 1-km downstream the sewage treatment plant discharge.

The lowest IBIA mean score at "Post-Ur" was only statistically different from the IBIA score at "UP1" ( $\mathrm{p}<0.05)$. Besides looking at the index score, we also analyzed the differences in mean values among reaches for each of its metrics. There was at least one significant difference in metric mean values among reaches for the following metrics: diversity, percentage of tetras, percentage of livebearers and percentage of fish tolerant to low DO (Figure 3). Native species richness and carnivorous fish percentage did not show significant differences in mean values among reaches.

Regarding the NSF-WQI, significant differences in mean values were detected in three cases: between "Post-Ur" and "UP1", between "Post-Ur" and "UP2" and between "Post-Ur" and "Ur" ( $\mathrm{p}<0.05)$. Further, the statistical analysis of WQIA mean values only showed significant differences between "Post-Ur" and "UP1" ( $<<0.05)$. The water quality variables for which we found significant statistical differences in mean values among reaches were $\mathrm{DO}$, $\mathrm{pH}, \mathrm{EC}, \mathrm{TAMC}, \mathrm{TC}$, E. coli, $\mathrm{Na}^{+}, \mathrm{SO}_{4}^{-2}, \mathrm{NO}_{2}^{-}$, $\mathrm{BOD}, \mathrm{TS}, \mathrm{SS}$ and turbidity (Figure $4 \mathrm{~A}$ and $\mathrm{B}$ ). Concentrations of $\mathrm{K}^{+}, \mathrm{NH}_{4}^{+}, \mathrm{NO}_{3}^{-}$and $\mathrm{PO}_{4}^{-3}$ did not show significant differences in mean values among reaches.

\section{Discussion}

Overall, both IBIA and the physicochemical indexes scores (i.e., WQIA and NSF-WQI) showed similar trends along the sampled reaches. The choice of using the biotic index or the abiotic ones would depend on evaluating the advantages and disadvantages of each index type, among which are the budget, lab equipment needed, time to get results and human resources availability. The relatively low-cost, low complexity and celerity achieved through the application of the fish biotic index represents a good alternative to the

Table 3. Indexes scores (mean $\pm S E$ ) at the sampled reaches along the Del Azul stream. Different superscript letters indicate significant differences $(\mathrm{p}<0.05)$ in mean index value between reaches. Please refer to the main text for reach acronyms meaning.

\begin{tabular}{|c|c|c|c|c|c|c|c|}
\hline \multirow[b]{2}{*}{ Index } & \multicolumn{7}{|c|}{ Reach name (distance from origin) } \\
\hline & $\begin{array}{c}\text { UP1 } \\
\text { (km 16) }\end{array}$ & $\begin{array}{c}\text { UP2 } \\
\text { (km 41) }\end{array}$ & $\begin{array}{c}\text { Pre-Ur } \\
\text { (km 59) }\end{array}$ & $\begin{array}{c}\text { Ur } \\
(\mathbf{k m ~ 6 5 )}\end{array}$ & $\begin{array}{l}\text { Post-Ur } \\
\text { (km 69) }\end{array}$ & $\begin{array}{c}\mathrm{L1} \\
(\mathrm{km} \mathrm{88})\end{array}$ & $\begin{array}{c}\text { L2 } \\
(\mathrm{km} \mathrm{148})\end{array}$ \\
\hline IBIA (value: 0-60) & $40 \pm 1.76^{a}$ & $34 \pm 3.34$ & $39 \pm 2.71$ & $42 \pm 3.44$ & $13 \pm 2.74^{b}$ & $33 \pm 5.57$ & $38 \pm 1.80$ \\
\hline $\operatorname{IBIA}(\%)$ & $66 \pm 2.93^{a}$ & $43 \pm 10.24$ & $65 \pm 4.52$ & $69 \pm 5.74$ & $21 \pm 4.56^{b}$ & $56 \pm 9.29$ & $63 \pm 3.00$ \\
\hline NSF-WQI (\%) & $64 \pm 2.24^{a}$ & $61 \pm 2.05^{a}$ & $60 \pm 0.99$ & $61 \pm 3.01^{a}$ & $39 \pm 1.64^{b}$ & $55 \pm 2.54$ & $58 \pm 3.48$ \\
\hline WQIA (\%) & $55 \pm 7.76^{a}$ & $46 \pm 6.41$ & $55 \pm 7.01$ & $45 \pm 8.16$ & $20 \pm 2.41^{b}$ & $50 \pm 4.18$ & $57 \pm 7.42$ \\
\hline
\end{tabular}



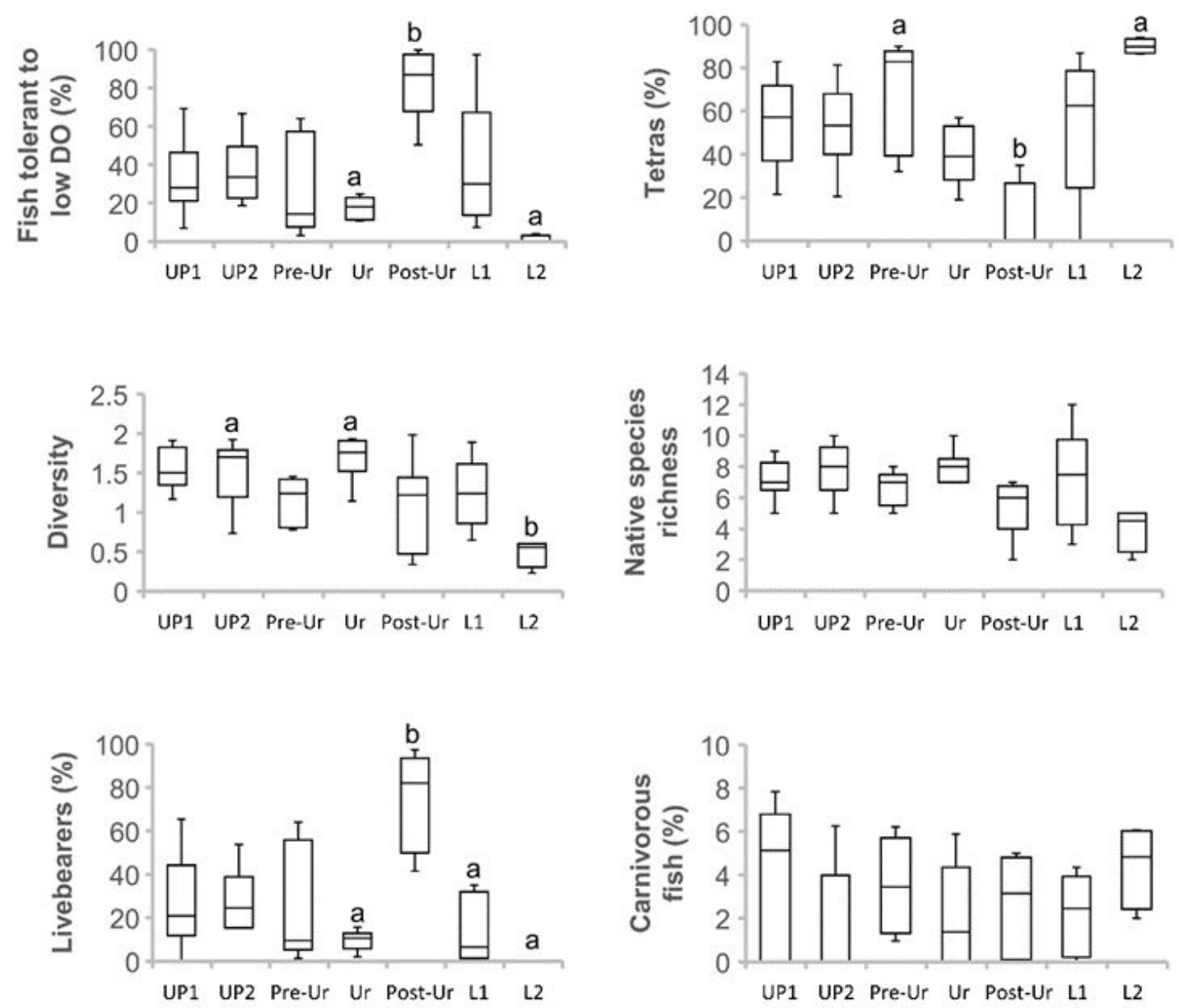

Figure 3. Boxplots of the metrics composing the IBIA at seven reaches along the Del Azul stream. Reaches are consecutively from the upper to the lower basin. Different letters above the error bars indicate statistical significance $(\mathrm{p}<0.05)$. Please refer to the main text for reach acronyms meaning.

more sophisticated physicochemical monitoring (de Zwart, 1995; Chapman et al., 1996; Holt \& Miller, 2011; Gonino et al., 2020). Besides, we already mentioned that biotic indexes could reflect past conditions, detect impairment associated with variables not accounted for in the physicochemical analyses or missed pulses of pollutants. Nonetheless, if there are available resources to perform both types of assessments (i.e., biological and physicochemical), it would be optimal to do so since the two types of variables synergistically combined would complement each other and better account for environmental issues helping to pinpoint the disturbance causing agent (Rodrigues Capítulo et al., 2010).

While there is no reach completely excluded from human intervention in the entire Del Azul stream basin that could serve as a zero-pollution reference site, the upper basin reaches "UP1" and "UP2" could still be thought as the least anthropically impacted ones based on their upstream location away from the urban area. However, these two reaches are still surrounded by agricultural fields so when analyzing the indexes scores, one should bear in mind that they are relative values, taking the highest value at the least impaired reach but not necessarily meaning a completely unmolested environment. For instance, De Geronimo et al. (2014) studied agricultural chemicals occurrence in Del Azul stream and detected traces of 7 compounds (out of 29 tested) used basin-wide: metsulfuron methyl, atrazine, diethyltoluamide, epoxiconazole, tebuconazole, piperonyl butoxide and metconazole. However, and as mentioned before, pesticide determinations were not performed in our study due to budget constraints.

Considering the above and agreeing with what we expected for the upper basin as a reference zone, the least impacted reaches were "UP1" (i.e., all three indexes showed statistically significant higher mean 

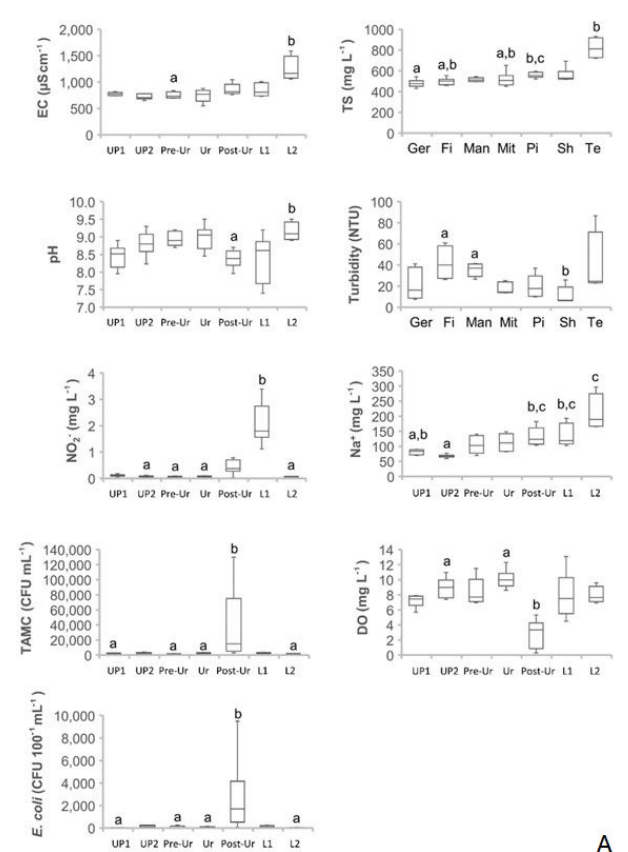
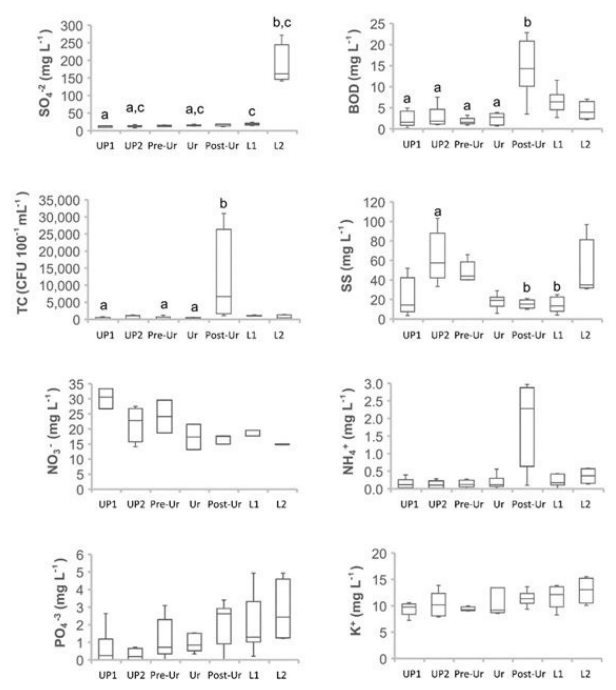

Figure 4. (A and B). Boxplots for physicochemical and microbiological variables at seven reaches along the Del Azul stream. Reaches are consecutively ordered from the upper to the lower basin. Different letters above the error bars indicate statistical significance $(\mathrm{p}<0.05)$. Please refer to the main text for reach acronyms meaning.

values here than at "Post-Ur") and "UP2" (i.e., the NSF-WQI had a significantly higher mean value here than at "Post-Ur"). Despite Figure 2 shows a drop in the IBIA score at "UP2" $(43 \pm 10.24 \%$, mean \pm SE), the mean value was not significantly different from the others. Further, "UP2" had the largest variability in the IBIA scores among reaches (e.g., SE at "UP2" was $10.24 \%$ whereas $\mathrm{SE}$ at "UP1" was $2.93 \%)$. We ignore what the variability in the IBIA at "UP2" could be attributed to since the physicochemical indexes did not vary as much (Table 3). Our study at least warns to keep a close eye on this rural reach which, as the others rural reaches, could be affected by unsustainable agricultural practices.

Interestingly, there was a peak of $69 \pm 5.74 \%$ (mean $\pm \mathrm{SE}$ ) in the IBIA score registered at "Ur" although not statistically different from the other reaches. Since "Ur" is located in the middle of the urban zone, this suggests that although the reach is modified due to human intervention, it still supports a diverse fish community. Dissolved oxygen levels at "Ur" were $10.10 \pm 0.51 \mathrm{mg} \mathrm{L}^{-1}$ $($ mean \pm SE) which probably contributed to make this reach significantly different from "Post-Ur" according to NSF-WQI. High DO levels found at "Ur" are most probably favored by limestone outcrops and concrete structures such as bridges and remnant foundations of old structures interfering with the water flow, facilitating water mixing and gas exchange with the atmosphere. Further, from Figure 3 it can be depicted that Shannon's diversity mean values here at "Ur" were the highest among reaches although only statistically different from "L2". The greater diversity found at "Ur" could be favored by the greater nutrient input due to urbanization and the high DO levels.

As seen both from the biotic and physicochemical indexes, the lowest scores were observed at "PostUr", the reach located $1-\mathrm{km}$ downstream the sewage treatment plant effluent. At this reach there was a reduced number of species, mostly dominated by the livebearers $J$. multidentata and C. decemmaculatus. Native species richness and Shannon's diversity index were $4.67 \pm 0.67$ and $0.88 \pm 0.20$ (mean $\pm S E)$, respectively. The two livebearer species dominating this reach are well known for being very prolific, with an omnivorous diet and tolerant to low DO concentrations due to a morphological adaptation conferred by their mouth pointing upwards and allowing them to breathe from the uppermost water layer richer in oxygen (Rosso, 2006). This agrees with the low DO levels found here: $2.08 \pm 0.60 \mathrm{mg} \mathrm{L}^{-1}$ (mean $\pm \mathrm{SE}$ ).

The dominance of the cyprinodontiforms J. multidentata and C. decemmaculatus in impaired 
environments has also been reported in lake Rodó (Uruguay), an artificial urban lake with a eutrophic condition associated with high nutrient loads from the urban area run-off and the groundwater supply. In the mentioned lake these two species accounted for as much as $98 \%$ of the total fish biomass (Quintans et al., 2009). Likewise, the most impaired urban reaches of the Suquía River (Córdoba Province, Argentina) had high proportions of these two species (Hued \& Bistoni, 2005). Fishes of the Cyprinodontiformes Order are widely distributed in neotropical regions and they are notorious for using deteriorated habitats where only few species can occur (Araujo et al., 2009; Dias et al., 2020). The low number and low percentage of characiforms was another characteristic of the most impaired reach (i.e., "Post-Ur"). Individuals from this order, especially of the family Characidae (represented here by tetras), have been reported to be sensitive to urban pollution in streams of the neotropical region of Brazil (Cunico et al., 2006). Besides DO, the other measured physicochemical and microbiological variables that most reflected water quality impairment at "Post-Ur" were $\mathrm{NH}_{4}^{+}, \mathrm{BOD}$ and the measures of bacterial loads TAMC, TC and E. coli (Figure $4 \mathrm{~A}$ and $\mathrm{B}$ ).

While all the rural reaches in the basin including the upper basin reaches are surrounded by fields subjected to agricultural practices which could have adverse effects on the freshwater ecosystems (Graziano et al., 2021), at least the uppermost basin reach (i.e., "UP1") showed good water quality and biotic integrity (i.e., all indexes mean scores were above $50 \%$ and significantly differed from "PostUr"). In general terms, it has been suggested that, compared to agriculture, urbanization would be a stronger anthropic pressure influencing the fish assemble structure (Utz et al., 2010; Trautwein et al., 2012) and that fish communities would be sensitive to even low levels of watershed urbanization but consistently higher and more variable levels of agricultural development (Chen \& Olden, 2020).

By looking at the trends for each of the indexes (Figure 2), it could be inferred that the two sampled reaches in the lower basin ("L1" and "L2") showed improved conditions compared to "Post-Ur". This occurs after the stream has passed through the urban area and travelled across the open land while being subjected to natural auto-depuration processes (e.g., aeration, dilution, microbiological breakdown of compounds). Moreover, apart from the anthropic pressure component, it is important to also account for the intrinsic characteristics of the basin which naturally influence the stream water quality. The stream in the lower part of the basin is characterized by having high concentration of solutes naturally occurring due to the interaction between the surface water and the shallow aquifer. The aquifer here is saline in nature, rich in sodium, chloride and sulphate (Zabala et al., 2015). Due to this interaction between surface and groundwater, EC levels in the stream at "L2" were the highest among reaches, ranging from 1,058 to $1,587 \mathrm{~S} \mathrm{~m}^{-1}$. These values almost doubled the values measured in the upper and middle basin. Turbidity and total solids also peaked at this reach (Figure 4B) but without necessarily implying pollution since the stream naturally accumulates sediments as it receives the surface runoff. These intrinsic properties of the water (e.g., high EC, TS, turbidity) could be limiting the occurrence of some fish species. Although IBIA mean value at "L2" (lower basin) was not significantly different from the other reaches, the fish assemblage was dominated by tetras (most exclusively Astyanax spp.). Further, as shown in the results section (Figure 3), Shannon's diversity index mean value at "L2" was the lowest: $0.49 \pm 0.09$ (mean $\pm S E$ ).

Although simplifying a system too much may result in the loss of some information, we still consider that in order to keep a monitoring program running through the years, the program should affect the minimum requirements in terms of human resources, equipment and budget. Otherwise, in times of economic crisis, with financial cuts and revision of project priorities, a sophisticated monitoring program could be at risk of being discontinued. Thus, we believe the simplicity of use of the IBIA approach could contribute in these aspects.

As a conclusion, our study showed that the IBIA based on the fish assemblage for Del Azul stream is suitable for monitoring the ecological condition of the stream. The three studied indexes (i.e., IBIA, NSF-WQI and WQIA) followed similar trends along the examined reaches, showing good conditions in the upper basin, poor conditions just downstream of the urban area and a recovery state further downstream in the basin. Further, this study serves as a baseline of the current biotic integrity of the system and future studies based on the IBIA should confirm if the baseline condition was maintained (did not change), worsened (e.g., with the magnification of current or the appearance of new pollution sources) or improved (e.g., with the implementation of green technologies, agroecology, 
etc.). Due to its simplicity, low cost and capability of detecting a broad spectrum of environmental disturbances, the IBIA constitutes a practical method for monitoring the ecological condition of the Del Azul stream, with potential for use in other streams of the pampean region.

\section{Acknowledgements}

We would like to thank the Comisión de Investigaciones Científicas de la Provincia de Buenos Aires for financing this study through its Centers Support Program. We are also grateful to our institute's technicians for the chemical analyses and help during field work: F. Altoaguirre, N. De Líbano, O. Floriani, S. Crespi, E. Queupán, J. Rodriguez, M. Silicani. We would also like to thank G. Ozán for volunteering during field work and A. Walker for reviewing the manuscript before submission.

\section{References}

ABBASI, T. and ABBASI, S.A. Water quality indices. Amsterdam, The Netherlands: Elsevier, 2012.

ALMEIDA, V.L.L., HAHN, N.S. and VAZZOLER, A.E.A.M. Feeding patterns in five predatory fishes of the high Paraná River floodplain (PR, Brazil). Ecology Freshwater Fish, 1997, 6(3), 123-133. http://dx.doi. org/10.1111/j.1600-0633.1997.tb00154.x.

American Public Health Association - APHA. Standard Methods for the Examination of Water and Wastewater. 21th ed. Washington: APHA, 2005.

ARAUJO, F.G. Adaptation of the index of biotic integrity based on fish assemblages in the Paraíba do Sul River, RJ, Brazil. Revista Brasileira de Biologia, 1998, 58, 547-558.

ARAUJO, F.G., FICHBERG, I., PINTO, B.C.T. and PEIXOTO, M.G. A preliminary index of biotic integrity for monitoring the condition of the Rio Paraíba do Sul, southeast Brazil. Environmental Management, 2003, 32(4), 516-526. http://dx.doi. org/10.1007/s00267-003-3003-9. PMid:14986900.

ARAÚJO, F.G., PEIXOTO, M.G., PINTO, B.C.T. and TEIXEIRA, T.P. Distribution of guppies Poecilia reticulata (Peters, 1860) and Phalloceros caudimaculatus (Hensel, 1868) along a polluted stretch of the Paraíba do Sul River, Brazil. Brazilian Journal of Biology $=$ Revista Brasileira de Biologia, 2009, 69(1), 41-48. http://dx.doi.org/10.1590/ S1519-69842009000100005. PMid:19347144.

BAE, Y.J., KIL, H.K. and BAE, K.S. Benthic macroinvertebrates for uses in stream biomonitoring and restoration. KSCE Journal of Civil Engineering, 2005, 9(1), 55-63. http://dx.doi.org/10.1007/ BF02829098.
BISTONI, M.A., HUED, A., VIDELA, M. and SAGRETTI, L. Efectos de la calidad del agua sobre las comunidades ícticas de la región central de Argentina. Revista Chilena de Historia Natural, 1999, 72, 325-335.

BOZZETTI, M. and SCHULZ, U.H. An index of biotic integrity based on fish assemblages for subtropical streams in southern Brazil. Hydrobiologia, 2004, 529(1), 133-144. http://dx.doi.org/10.1007/s10750004-5738-6.

BRAUN, N., DE LIMA, R.L., MORAES, B., LORO, V.L. and BALDISSEROTTO, B. Survival, growth and biochemical parameters of silver catfish, Rhamdia quelen (Quoy \& Gaimard, 1824), juveniles exposed to different dissolved oxygen levels. Aquaculture Research, 2006, 37(15), 1524-1531. http://dx.doi. org/10.1111/j.1365-2109.2006.01589.x.

BROWN, R.M., MC CLELLAND, N.I., DEININGER, R.A. and TOZER, R.G. Water quality index - do we dare? Water \& Sewage Works, 1970, 117, 339-343.

BUSS, D.F., CARLISLE, D.M., CHON, T.S., CULP, J., HARDING, J.S., KEIZER-VLEK, H.E., ROBINSON, W.A., STRACHAN, S., THIRION, C. and HUGHES, R.M. Stream biomonitoring using macroinvertebrates around the globe: a comparison of large-scale programs. Environmental Monitoring and Assessment, 2015, 187(1), 4132. http://dx.doi. org/10.1007/s10661-014-4132-8. PMid:25487459.

CALlisTO, M., CASTRO, D., MORAIS, L., HUGHES, F.M., KIMURA, A., ALVES, R., FREITAS, V., GAGLIARDI, L., GUIMARÁES, L.C., GUTIERREZ, M.A., LIGEIRO, R., MIRANDA, R.F., RESENDE, F. and SALES, S.C.M. Gestão eficiente de bacias hidrográficas no Brasil: dificuldades e perspectivas de soluçôes. Natureza \& Conservação, 2012, 10(1), 1-4. http:// dx.doi.org/10.4322/natcon.2012.016.

CARVALHO, L.N., FERNANDES, C.H.V. and MOREIRA, V.S.S. Alimentação de Hoplias malabaricus (Bloch, 1794)(Osteichthyes, Erythrinidae) no rio Vermelho, Pantanal Sul MatoGrossense. Revista Brasileira de Zoociências, 2002, 4, 227-236.

CASATTI, L., FERREIRA, C.P. and LANGEANI, F. A fish-based biotic integrity index for assessment of lowland streams in southeastern Brazil. Hydrobiologia, 2009, 623(1), 173-189. http://dx.doi.org/10.1007/ s10750-008-9656-x.

CHAPMAN, D., JACKSON, J. and KREBS, F. Water quality monitoring-A practical guide to the design and implementation of Freshwater Quality Studies and Monitoring Programmes. In: BARTRAM, J. and BALANCE, R., ed. Biological Monitoring. UNEP/ WHO, 1996, pp. 267-305.

CHEN, K. and OLDEN, J.D. Threshold responses of riverine fish communities to land use conversion across regions of the world. Global Change Biology, 
2020, 26(9), 4952-4965. http://dx.doi.org/10.1111/ gcb.15251. PMid:32564461.

CLAPS, A. Informes sobre Desagües en el Sur de la Provincia de Buenos Aires. Ministerio de Obras Públicas de la Provincia de Buenos Aires. Taller de Impresiones Oficiales, La Plata, Argentina, 1913.

COLAUTTI, D.C. and REMES LENICOV, M. Alimentación de la carpa (Cyprinus carpio Linnaeus 1758) en la laguna de Lobos, Provincia de Buenos Aires, Argentina. Ecología Austral, 2001, 11, 69-78.

CUNICO, A.M., AGOSTINHO, A.A. and LATINI, J.D. Influência da urbanização sobre as assembléias de peixes em três córregos de Maringá, Paraná. Revista Brasileira de Zoologia, 2006, 23(4), 1101-1110. http:// dx.doi.org/10.1590/S0101-81752006000400018.

DE GERONIMO, E., APARICIO, V.C., BÁRBARO, S., PORTOCARRERO, R., JAIME, S. and COSTA, J.L. Presence of pesticides in surface water from four sub-basins in Argentina. Chemosphere, 2014, 107, 423-431. http://dx.doi.org/10.1016/j. chemosphere.2014.01.039. PMid:24548646.

DE ZWART, D. Monitoring water quality in the future, Volume 3. Biomonitoring, 1995

DIAS, M.S., FARIA, I.F., GUARIDO, P.C.P., TERESA, F.B., AQUINO, P.P.U. and QUIMBAYO, J.P. Historical distribution and current drivers of guppy occurrence in Brazil. Journal of Fish Biology, 2020, 96(4), 877-885. http://dx.doi.org/10.1111/ jfb.14271. PMid:31998966.

DICKENS, C., COX, A., JOHNSTON, R.M., DAVISON, S., HENDERSON, D., MEYNELL, P.J., and SHINDE, V. State of Knowledge 9: Monitoring the health of the Greater Mekong's Rivers. France: CGIAR, 2018

DIOVISALVI, N., BERASAIN, G., UNREIN, F., COLAUTTI, D., FERMANI, P., LLAMES, M.E., TORREMORELL, A., LAGOMARSINO, L., PEREZ, G., ESCARAY, R., BUSTINGORRY, J.F., FERRARO, M. and ZAGARESE, H.E. Chascomús: estructura y funcionamiento de una laguna pampeana turbia. Ecología Austral, 2010, 20, 115-127.

EDUARDO, J., BICUDO, P.W. and JOHANSEN, $\mathrm{K}$. Respiratory gas exchange in the airbreathing fish, Synbranchus marmoratus. Environmental Biology of Fishes, 1979, 4(1), 55-64. http://dx.doi.org/10.1007/ BF00005928.

EICHBAUM ESTEVES, K. and ALEXANDRE, C.V. Development of an index of biotic integrity based on fish communities to assess the effects of rural and urban land use on a stream in southeastern Brazil. International Review of Hydrobiology, 2011, 96(3), 296-317. http://dx.doi.org/10.1002/ iroh.201111297.

ENTRAIGAS, I. and VERCELLI, N. Los paisajes de la cuenca del arroyo Del Azul. Mar del Plata, Argentina: Editorial Martin, 2013.
ESCALANTE, A.H. Contribución al conocimiento de las relaciones tróficas de peces de agua dulce del área platense. III. Otras especies. Limnobios, 1983 , 2, 453-463

ESCALANTE, A.H. Dieta comparativa de Cheirodon I. interruptus (Osteichthyes Characidae) en ambientes lénticos y lóticos de la Provincia de Buenos Aires. Revista del Museo de La Plata, 1987, 14, 35-45.

ESTEVES, K.E. Feeding ecology of three Astyanax species (Characidae, Tetragonopterinae) from a floodplain lake of Mogi-Guaçú River, Paraná River Basin, Brazil. Environmental Biology of Fishes, 1996, 46(1), 83-101. http://dx.doi.org/10.1007/ BF00001701.

FAUSCH, K.D., KARR, J.R. and YANT, P.R. Regional application of an index of biotic integrity based on stream fish communities. Transactions of the American Fisheries Society, 1984, 113(1), 39-55. http://dx.doi. org/10.1577/1548-8659(1984)113<39:RAOAIO $>2.0 . \mathrm{CO} ; 2$.

FAUSCH, K.D., LYONS, J., KARR, J.R. and ANGERMEIER, P.L. Fish communities as indicators of environmental degradation. In ADAMS, S. M. ed. Biological indicators of stress in fish. Bethesda, Maryland: American Fisheries Society Symposium, 1990, pp. 123-144.

FEIJOÓ, C.S., GIORGI, A., GARCÍA, M.E. and MOMO, F. Temporal and spatial variability in streams of a pampean basin. Hydrobiologia, 1999, 394, $41-$ 52. http://dx.doi.org/10.1023/A:1003583418401.

FERNÁNDEZ, E.M., FERRIZ, R.A., BENTOS, C.A. and LÓPEZ, G.R. Dieta y ecomorfología de la ictiofauna del arroyo Manantiales, provincia de Buenos Aires, Argentina. Revista del Museo Argentino de Ciencias Naturales, 2012, 14, 1-13. http://dx.doi. org/10.22179/REVMACN.14.206.

FERREIRA, C.P. and CASATTI, L. Stream biotic integrity assessed by fish assemblages in the Upper Rio Paraná basin. Biota Neotropica, 2006, 6, 1-25.

FRANÇA, J.S. and CALLISTO, M. Monitoramento ambiental participativo de qualidade de água: a comunidade escolar como parceira na conservação de biodiversidade. Estudos Ambientais. Rio de Janeiro, Brazil. Interciencia, 2017, 3, 40-51.

FRANCO, C.R.C. Estudo ultaestrutural do estômago de dois Teleósteos: Hypostomus commersonnii (Reis et al., 1990) e Rhamdia branneri (Hasemann, 1911) [Dissertação de Mestrado]. Curitiba: Universidade Federal do Paraná, 1994.

GARCÍA, M.L., SOLARI, L.C. and GARCÍA DE SOUZA, J.R. Feeding ecology of the siluriform Pimelodella laticeps Eigenmann, 1917 in a Pampean stream from Argentina. Revista del Museo Argentino de Ciencias Naturales, 2017, 19, 211-223. http://dx.doi. org/10.22179/REVMACN.19.519. 
GIORGI, A., FEIJOÓ, C. and TELL, G. Primary producers in a Pampean stream: temporal variation and structuring role. Biodiversity and Conservation, 2005, 14(7), 1699-1718. http://dx.doi.org/10.1007/ s10531-004-0694-z.

GODWIN, A. and OBORAKPORORO, O. Surface water quality assessment of warri metropolis using Water Quality Index. International Letters of Natural Sciences, 2019, 74, 18-25. http://dx.doi. org/10.18052/www.scipress.com/ILNS.74.18.

GOMES, L.C., GOLOMBIESKI, J.I., GOMES, A.R.C. and BALDISSEROTTO, B. Biologia do jundiá Rhamdia quelen (Teleostei, Pimelodidae). Ciência Rural, 2000, 30(1), 179-185. http://dx.doi. org/10.1590/S0103-84782000000100029.

GONINO, G., BENEDITO, E., CIONEK, V.D.M., FERREIRA, M.T. and OLIVEIRA, J.M. A fishbased index of biotic integrity for neotropical rainforest sandy soil streams, Southern Brazil. Water (Basel), 2020, 12(4), 12-15. http://dx.doi. org/10.3390/w12041215.

GraZiANO, M., GIORGI, A. and FEIJOÓ, C. Multiple stressors and social-ecological traps in Pampean streams (Argentina): a conceptual model. The Science of the Total Environment, 2021, 765, 142785. http://dx.doi.org/10.1016/j. scitotenv.2020.142785. PMid:33097269.

HAMMER, Ø., HARPER, D.A. and RYAN, P.D. PAST: paleontological statistics software package for education and data analysis. Palaeontologia Electronica, 2001, 4, 9.

HARRIS, J.H. and SILVEIRA, R. Large scale assesments of river health using an Index of Biotic Integrity with low-diversity fish communities. Freshwater Biology, 1999, 41(2), 235-252. http://dx.doi.org/10.1046/ j.1365-2427.1999.00428.x.

HERING, D., FELD, C.K., MOOG, O. and OFENBÖCK, T. Cook book for the development of a Multimetric Index for biological condition of aquatic ecosystems: experiences from the European AQEM and STAR projects and related initiatives. In: M.T. Furse, D. Hering, K. Brabec, A. Buffagni, L. Sandin and P.F.M. Verdonschot. The ecological status of European rivers: evaluation and intercalibration of assessment methods. Dordrecht: Springer, 2006, pp. 311-324. http://dx.doi.org/10.1007/978-1-40205493-8_22.

HOLT, E.A. and MILLER, S.W. Bioindicators: using organisms to measure environmental impacts. Nature Education Knowledge, 2011, 2, 8.

HUED, A.C. and BISTONI, M.A. Development and validation of a Biotic Index for evaluation of environmental quality in the central region of Argentina. Hidrobiologia, 2005, 543(1), 279-298. http://dx.doi.org/10.1007/s10750-004-7893-1.
HUED, A.C., CARUSO, M.N., WUNDERLIN, D.A. and BISTONI, M.A. Field and in vitro evaluation of ammonia toxicity on native fish species of the central region of Argentina. Bulletin of Environmental Contamination and Toxicology, 2006, 76(6), 984-991. http://dx.doi.org/10.1007/s00128-006-1015-x. PMid:16855905.

HUGHES, G.M., ALBERS, C., MUSTER, D. and GÖTZ, K.H. Respiration of the carp, Cyprinus carpio L., at 10 and $20 \mathrm{C}$ and the effects of hypoxia. Journal of Fish Biology, 1983, 22(5), 613-628. http://dx.doi. org/10.1111/j.1095-8649.1983.tb04221.x.

IGLESIAS, C., MAZZEO, N., GOYENOLA, G., FOSALBA, C., TEIXEIRA DE MELlO, F., GARCIA, S. and JEPPESEN, E. Field and experimental evidence of the effect of Jenynsia multidentata, a small omnivorous-planktivorous fish, on the size distribution of zooplankton in subtropical lakes. Freshwater Biology, 2008, 53(9), 1797-1807. http://dx.doi.org/10.1111/j.13652427.2008.02007.x.

KARR, J.R. and CHU, E.W. Introduction: sustaining living rivers. In: M. JUNGWIRTH, S. MUHAR and S. SCHMUTZ, eds. Assessing the ecological integrity of running waters. Dordrecht: Springer, 2000, pp. 1-14. http://dx.doi.org/10.1007/978-94-011-4164-2_1.

KARR, J.R. and CHU, E.W. Restoring life in running waters: better biological monitoring. Washington: Island Press, 1999.

KARR, J.R. Assessment of biotic integrity using fish communities. Fisheries (Bethesda, Md.), 1981, 6(6), 21-27. http://dx.doi.org/10.1577/15488446(1981)006<0021:AOBIUF>2.0.CO;2.

KARR, J.R. Seven foundations of biological monitoring and assessment. Biologia Ambientale, 2006, 20, 7-18.

KARR, J.R., FAUSCH, K.D., ANGERMEIER, P.L., YANT, P.R. and SCHLOSSE, I.J. Assessing biological integrity in running waters: a method and its rationale. Champaign, Illinois: Illinois Natural History Survey, 1986. Special Publication, vol. 5.

KOKUBUN, É.E., BONATO, K.O., BURRESS, E.D. and FIALHO, C.B. Diet and body shape among populations of Bryconamericus iheringii (Otophysi: Characidae) across the Campos Sulinos ecosystem. Neotropical Ichthyology, 2018, 16(4), 1-14. http:// dx.doi.org/10.1590/1982-0224-20170167.

LAMPERT, V.R., AZEVEDO, M.A. and FIALHO, C.B. Reproductive biology of Bryconamericus iheringii (Ostariophysi: Characidae) from rio Vacacaí, RS, Brazil. Neotropical Ichthyology, 2004, 2(4), 209-215. http://dx.doi.org/10.1590/S167962252004000400003.

LANDWEHR, J.M. and DEININGER, R.A. A comparison of several water quality indexes. Journal - Water Pollution Control Federation, 1976, 48, 954958. 
LICURSI, M. and GÓMEZ, N. Aplicación de índices bióticos en la evaluación de la calidad del agua en sistemas lóticos de la Llanura Pampeana Argentina a partir del empleo de diatomeas. Biologia Acuatica, 2003, 21, 31-49.

LÓPEZ-LÓPEZ, E. and SEDEÑO-DÍAZ, J.E. Biological indicators of water quality: the role of fish and macroinvertebrates as indicators of water quality. In: R. ARMON and O. HÄNNINEN. Environmental Indicators. Dordrecht: Springer, 2015. pp. 643-661. http://dx.doi.org/10.1007/978-94017-9499-2_37.

MADALINA, P. and GABRIELA, B.I. Water quality index - an instrument for water resources management. Aerulşi Apa. Componente ale Mediului, 2014, 391-398.

MARCIANO, F.T., CHAUDHRY, F.H. and RIBEIRO, M.C.L.B. Evaluation of the index of biotic integrity in the Sorocaba River Basin (Brazil, SP) based on fish communities. Acta Limnologica Brasiliensia, 2004, 16, 225-237.

MATHURIAU, C., MERCADO SILVA, N., LYONS, J. and MARTÍNEZ RIVERA, L.M. Fish and macroinvertebrates as freshwater ecosystem bioindicators in Mexico: current state and perspectives. In: H. G. BRAUCH, ed. Hexagon series on human and environmental security and peace. Heidelberg: Springer-Verlag, 2011, pp. 251-2611.

MATTEUCCI, S., RODRIGUEZ, A., SILVA, M. and DE HARO, C. Ecorregiones y complejos ecosistémicos argentinos. Buenos Aires, Argentina: Orientación Gráfica Editora, 2012, pp. 309-348.

MENNI, R.C. Monografías del Museo Argentino de Ciencias Naturales. Buenos Aires: Estudio Sigma S.R., 2004, L, 1-316.

MONTENEGRO, L.A., DA SILVA, N.B., DO NASCIMENTO, W.S. and CHELLAPPA, S. Anatomy and histology of the digestive tract and feeding habits of the marbled swamp eel, Synbranchus marmoratus. Animal Biology Journal, 2012, 3, 127 143.

MUNNÉ, A., GINEBREDA, A. and PRAT, N. Experiences from surface water quality monitoring: the $E U$ water framework directive implementation in the Catalan river basin district. USA: Springer, 2015.

NUNES, D.M. and HARTZ, S.M. Feeding dynamics and ecomorphology of Oligosarcus jenynsii (Gunther, 1864) and Oligosarcus robustus (Menezes, 1969) in the Lagoa Fortaleza, southern Brazil. Brazilian Journal of Biology = Revista Brasileira de Biologia, 2006, 66(1A), 121-132. http://dx.doi.org/10.1590/S151969842006000100016 . PMid:16680315.

OLIVEIRA, I.D.R. and SOARES, L.S.H. Alimentação da tainha Mugil platanus Günther, 1880) (Pisces: Mugilidae), da regiấo estuarino-lagunar de Cananéia,
São Paulo, Brasil. Boletim do Instituto de Pesca, 1996, 23, 95-104.

PINTO, B.C.T. and ARAUJO, F.G. Assessing of biotic integrity of the fish community in a heavily impacted segment of a tropical river in Brazil. Brazilian Archives of Biology and Technology, 2007, 50(3), 489-502. http://dx.doi.org/10.1590/S151689132007000300015.

PINTO, B.C.T., ARAUJO, F.G. and HUGHES, R.M. Effects of landscape and riparian condition on a fish index of biotic integrity in a large southeastern Brazil river. Hydrobiologia, 2006, 556(1), 69-83. http:// dx.doi.org/10.1007/s10750-005-9009-y.

PLAUL, S.E., BARBEITO, C.G. and DÍAZ, A.O. Histochemical differences along the intestine of Corydoras paleatus (Siluriformes: Callichthyidae). Revista de Biologia Tropical, 2016, 64(1), 327-340. http://dx.doi.org/10.15517/rbt.v64i1.18235. PMid:28862822.

POUILLY, M. and CAMACHO, J. Composición de la comunidad de peces en la cuenca del río Iténez (Bolivia). In: P. A. VAN DAMME, M. MALDONADO, M. POUILLY and C. R. C. DORIA, eds. Aguas del Iténez o Guaporé: Recursos hidrobiológicos de un patrimonio binacional (Bolivia y Brasil). Marseille: IRD Éditions, 2013, pp. 157-171.

QUINTANS, F., SCASSO, F., LOUREIRO, M. and YAFE, A. Diet of Cnesterodon decemmaculatus (Poeciliidae) and Jenynsia multidentata (Anablepidae) in a hypertrophic shallow lake of Uruguay. Iheringia. Série Zoologia, 2009, 99(1), 99-105. http://dx.doi. org/10.1590/S0073-47212009000100014.

RANTIN, F.T., KALININ, A.L., GLASS, M.L. and FERNANDES, M.N. Respiratory responses to hypoxia in relation to mode of life of two erythrinid species (Hoplias malabaricus and Hoplias lacerdae). Journal of Fish Biology, 1992, 41(5), 805-812. http:// dx.doi.org/10.1111/j.1095-8649.1992.tb02708.x.

RODRIGUES CAPÍTUlo, A., GÓMEZ, N., GIORGI, A. and FEIJOÓ, C. Global changes in pampean lowland streams (Argentina): implications for biodiversity and functioning. In: R.J. STEVENSON and S. SABATER. Global change and river ecosystems. implications for structure, function and ecosystem services. Dordrecht: Springer, 2010, pp. 53-70. http://dx.doi.org/10.1007/978-94-0070608-8_5.

RODRIGUES CAPÍTUlO, A., TANGORRA, M. and OCÓN, C. Use of benthic macroinvertebrates to assess the biological status of Pampean streams in Argentina. Aquatic Ecology, 2001, 35(2), 109-119. http://dx.doi.org/10.1023/A:1011456916792.

RODRÍGUEZ, L., GONZÁLEZ CASTELAIN, J., PELUSO, F. and OTHAX, N. Desarrollo de un Indice de Calidad de Agua para la cuenca del Arroyo del Azul, Buenos Aires, Argentina. Actas del I Congreso 
Internacional de Hidrología de Llanuras, 2010, pp. 713-720.

RODRÍGUEZ, M.A. and LEWIS JÚNIOR, W.M. Structure of fish assemblages along environmental gradients in floodplain lakes of the Orinoco River. Ecological Monographs, 1997, 67(1), 109-128. http:// dx.doi.org/10.1890/0012-9615(1997)067[0109:SO FAAE]2.0.CO;2.

RODRÍGUEZ-OLARTE, D. and TAPHORN, D.C. Los peces como indicadores biológicos: aplicación del Índice de Integridad Biótica en ambientes acuáticos de los llanos occidentales de Venezuela. Biollania, $1995,11,27-55$.

ROSENBERG, D.M. and RESH, V.H. Freshwater biomonitoring and benthic macroinvertebrates. New York: Chapman \& Hall, 1993.

ROSSO, J. J. Peces pampeanos: guía y ecología. Buenos Aires: Literature of Latin America, 2006.

RUARO, R., GUBIANI, E.A., CUNICO, A.M., MORETTO, Y. and PIANA, P.A. Comparison of fish and macroinvertebrates as bioindicators of Neotropical streams. Environmental Monitoring and Assessment, 2016, 188(1), 45. http://dx.doi. org/10.1007/s10661-015-5046-9. PMid:26687088.

SCARDI, M., TANCIONI, L. and CATAUDELLA, S. Monitoring methods based on fish. London: Wiley, 2006. http://dx.doi.org/10.1002/0470863781.ch8.

SOUZA, G.B.G. and VIANNA, M. Fish-based indices for assessing ecological quality and biotic integrity in transitional waters: A systematic review. Ecological Indicators, 2020, 109, 105665. http://dx.doi. org/10.1016/j.ecolind.2019.105665.

SPRINGER, M. Biomonitoreo acuático. Revista de Biología Tropical, 2010, 58, 53-59.

TRAUTWEIN, C., SCHINEGGER, R. and SCHMUTZ, S. Cumulative effects of land use on fish metrics in different types of running waters in Austria. Aquatic Sciences, 2012, 74(2), 329-341. http://dx.doi.org/10.1007/s00027-011-0224-5. PMid:25983526.

U. S. ENVIRONMENTAL PROTECTION AGENCY - USEPA. Volunteer stream monitoring: a methods manual. Washington: U.S. Environmental Protection Agency, 1997.

UTZ, R.M., HILDERBRAND, R.H. and RAESLY, R.L. Regional differences in patterns of fish species loss with changing land use. Biological Conservation, 2010, 143(3), 688-699. http://dx.doi.org/10.1016/j. biocon.2009.12.006.

VARNI, M., BARRANQUERO, R.S. and ZEME, $S$. Groundwater and surface water interactions in flat lands: the importance of ecological and flow regulation perspectives. Sustainable Water Resources Management, 2019, 5(4), 1791-1801. http://dx.doi. org/10.1007/s40899-019-00334-1.

VILELLA, F.S., BECKER, F.G. and HARTZ, S.M. Diet of Astyanax species (Teleostei, Characidae) in an Atlantic forest river in Southern Brazil. Brazilian Archives of Biology and Technology, 2002, 45(2), 223-232. http://dx.doi.org/10.1590/S151689132002000200015.

VILLARES JUNIOR, G.A. and GOITEIN, R. Differences in the feeding of Rhamdia quelen (Siluriformes, Heptapteridae) in four distinct lotic systems. Brazilian Journal of Biology $=$ Revista Brasileira de Biologia, 2015, 75(3), 650-654. http://dx.doi.org/10.1590/1519-6984.20313. PMid:26465726.

WATER RESEARCH CENTER. 2021 [viewed 18 Feb. 2021]. Available from: https://www.water-research. net/index.php/water-treatment/water-monitoring/ monitoring-the-quality-of-surfacewaters.

ZABALA, M.E., MANZANO, M. and VIVES, L. The origin of groundwater composition in the Pampeano Aquifer underlying the Del Azul Creek basin, Argentina. The Science of the Total Environment, 2015, 518, 168-188. http://dx.doi.org/10.1016/j. scitotenv.2015.02.065. PMid:25747376.

ZAR, J.H. Biostatistical analysis. Upper Saddle River: Pearson Education, 2014.

Received: 18 August 2020 Accepted: 26 January 2021

Associate Editor: Ronaldo Angelini. 